\title{
Food of the Otter on the Fiora River (Central Italy)
}

\author{
DIETA WYDRY NA RZECE FIORA, WŁOCHY
}

\author{
Guglielmo ARCÃ \& Claudio PRIGIONI
}

Arcà G. \& Prigioni C., 1987: Food of the otter on the Fiora river (Central Italy). Acta theriol., 32: 10: 134-140 [With 1 Table \& 2 Figs.]

The food of the otter Lutra lutra (Linnaeus, 1758) was studied on the Fiora River (Central Italy) by the analysis of 148 spraints collected at monthly intervals from August to October 1982 and from January to April 1983. Fish was the most important food (relative frequency $74.2 \%$ ), with a prevalence of cyprinids during all months. Barbus plebejus, Condrostoma genei and Leuciscus cephalus were the principal species of cyprinids taken by otters. Snakes were the second in order of importance as prey. The diet changed little during the year.

[Assessorato Programmazione, Ufficio Parchi e Riserve Naturali, Regione Lazio, via C. Colombo 212, 00145 Roma and Dipartimento di Biologia Animale, Università di Pavia, Piazza Botta, 9, 27100 Pavia, Italia; members of Gruppo Lontra Italia].

\section{INTRODUCTION}

Several studies on the otter's diet, Lutra lutra (Linnaeus, 1758) by the analysis of the food remains in the spraints have been carried out in Northern Europe, especially in Sweden (Erlinge, 1967 and 1969), in Ireland (Fairley, 1972; Fairley \& Wilson, 1972; Gormally \& Fairley 1982) and in Great Britain (Hewson, 1973; Webb, 1975; Jenkins et al., 1979; Jenkins \& Harper, 1980; Mason \& Macdonald, 1980; Wise et al., 1981; Chanin, 1981). By contrast, little information has been collected in the countries of the Mediterranean basin (Portugal and Greece: Macdonald \& Mason, 1982a and 1982b; Spain: Callejo \& Delibes, 1983; Lopez-Nieves \& Hernando Casal, 1984; Albania: Prigioni et. al., 1986).

No data are available concerning the food of the otter in Italy. In this paper we report the results of an analysis of prey items from spraints collected on the Fiora River (Latium and Tuscany regions) which supports one of the last populations of otters in Italy (Arcà, 1986).

\section{STUDY AREA}

The Fiora River rises in the mount Amiata (Southern Tuscany), at an altitude of $646 \mathrm{~m}$, and, after a course of $80 \mathrm{~km}$, flows into the Tirrenian Sea (Northern Latium). Its catchment covers $853 \mathrm{~km}^{2}$ and its average flow near the outlet is $6.3 \mathrm{~m}^{3} \mathrm{~s}^{-1}$, (annual range from $18 \mathrm{~m}^{3} \mathrm{~s}^{-1}$ in December, to $3 \mathrm{~m}^{3} \mathrm{~s}^{-1}$, in August). Spraints were collected along the $40 \mathrm{~km}$ central stretch of the river, where it often runs through deep gorges of tufaceous and calcareous rocks. In this stretch, wide 
woods of Quercus spp. and Ostrya carpinifolia occur, and the riparian vegetation also includes prevalently Populus spp., Salix spp., Ulmus minor and Alnus glutinosa.

The Fiora River is used both for gravel extraction and for angling, but it seems to maintain good populations of fish, while Crustacea, such as Austropotamobius pallipes, also occur. Since the population density in the Fiora catchment is very low $\left(30\right.$ people $\left./ \mathrm{km}^{2}\right)$ water pollution is negligible. In fact an analysis of the macrobenthic animal community, using a biotic index, shows that the biological quality of the Fiora River is good (Belfiore et al., in press).

\section{METHODS}

During a field survey of otters on the Fiara River, a total of 148 spraints was collected from August to October 1982 and from January to April 1983. Spraints were generally taken during two visits in each month and stored individually in polythene bags. Only fresh-looking spraints were collected to be representative of the monthly samples.

Dried spraints were cleaned by a solution of oxidizing agent "Steradent" (Webb, 1976) for some days to remove mucus and were washed through a sieve of $0.5 \mathrm{~mm}$ mesh. The identification of fish remains, particularly of cyprinids, in the spraints was principally carried out with a help of a personal collection of pharyngeal teeth, but the keys of Webb (1976), Watson (1978) and Camby et al. (1984) were also used. Snakes were identified on the bases of the scales and the jaw bones. Detailed identification of insects, Crustacea and vegetable matter was not undertaken.

The results of the analysis of prey items are reported as frequency of occurrence (percentage of spraints containing a specific taxon) and as relative frequency (percentage of each prey item in the total number of items).

\section{RESUltS}

The composition of the otter's diet, obtained by the analysis of all spraints collected, is summarized in Table 1 and the proportion of the main categories of food is given in Fig. 1. Fish was the most important component $(74.2 \%)$ of the diet; they belonged predominantly to the family Cyprinidae, with eight species. The other families (Anguillidae, Salmonidae, Percidae) were scarcely represented, with a relative frequency that ranged from $1.4 \%$ to $2.9 \%$. Snakes were the second category of food in order of importance, followed by frogs, probably Rana esculenta, and insects, prevalently Coleoptera. Crustacea, mammals and vegetable matter were negligible categories of food.

Fig. 2 shows the monthly variation of prey items in the otter's diet from August to April (no data were collected in November and December). Within cyprinids, that held a high relative frequency (from $50.0 \%$, in August to $85.7 \%$, in March), Barbus plebejus, Condrostoma genei and in part Leuciscus cephalus were the most important prey items taken in all months, while the other species occurred discontinuously and gen- 
Table 1

The composition of the otter's diet in the Fiora River (Central Italy) $\mathrm{N}=$ number of spraints containing a specific taxon; $\mathrm{F} \%=$ frequency of occurrence; $\mathrm{RF} \%=$ relative frequency; Total: number of spraints analyzed (left) and number of prey items (right) in parenthesis.

\begin{tabular}{lrrr}
\hline Taxon & N & F \% & FR \% \\
\hline Insects & 15 & 10.1 & 5.4 \\
Crustacea & 2 & 1.3 & 0.7 \\
Fishes & 147 & 99.3 & 74.2 \\
Salmonidae & 8 & 5.4 & 2.9 \\
Cyprinidae & 143 & 96.6 & 66.4 \\
$\quad$ Rutilus rubilio & 3 & 2.0 & 1.1 \\
$\quad$ Leuciscus cephalus & 22 & 14.9 & 7.9 \\
$\quad$ Scardinius erythrophthalmus & 14 & 9.4 & 5.0 \\
Alburnus albidus & 4 & 2.7 & 1.4 \\
Condrostoma genei & 46 & 31.1 & 16.4 \\
Barbus plebejus & 53 & 35.8 & 18.9 \\
$\quad$ Carassius carassius & 2 & 1.3 & 0.7 \\
$\quad$ Cyprinus carpio & 1 & 0.7 & 0.4 \\
$\quad$ Unidentified cyprinids & 41 & 27.7 & 14.6 \\
Anguilla anguilla & 6 & 4.0 & 2.1 \\
Percidae & 4 & 2.7 & 1.4 \\
Unidentified fishes & 4 & 2.7 & 1.4 \\
Amphibians (Rana sp.) & 14 & 9.4 & 5.0 \\
Reptiles (Natrix sp.) & 38 & 25.7 & 13.6 \\
Mammals (Sorex sp.) & 1 & 0.7 & 0.4 \\
Vegetable (seeds) & 2 & 1.3 & 0.7 \\
Total & $(148)$ & & $(280)$ \\
\hline
\end{tabular}

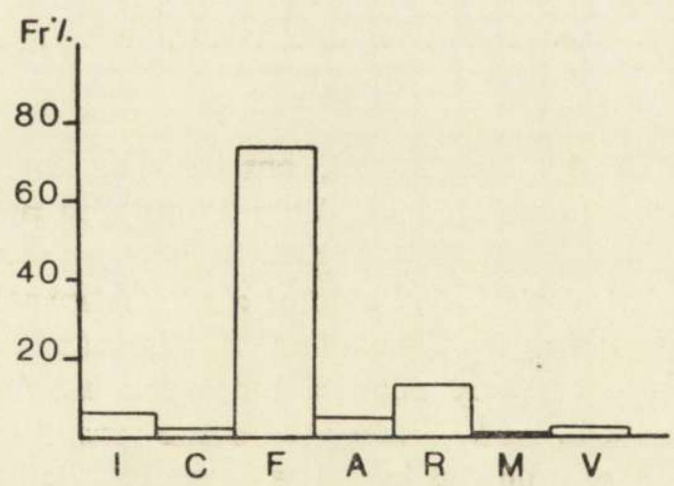

Fig. 1. The main categories of food in the otter diet of Fiora River. (FR $\%=$ relative frequency; $\mathrm{I}=$ insects, $\mathrm{C}=$ Crustacea, $\mathrm{F}=$ fishes, $\mathrm{A}=$ amphibians, $\mathrm{R}=$ reptiles, $\mathrm{M}=$ mammals, $\mathrm{V}=$ vegetable).

erally with a low relative frequency. An analogous trend could be observed for salmonids, percids and eels. Snakes were a frequent prey item in all months, with a peak $(27.3 \%)$ in April, when cyprinids seemed to decrease in the otter's diet. Frogs decreased from September to 
January and did not occur in other months, while insects showed a discontinuous presence with a peak in February. For cyprinids, a comparision of the vertebrae and the pharyngeal teeth from spraints with those from specimens of known length, suggested that the majority of prey items eaten by the otter were $10-15 \mathrm{~cm}$ in length. Also for snakes. mainly youngs, small size specimens were taken by otters.
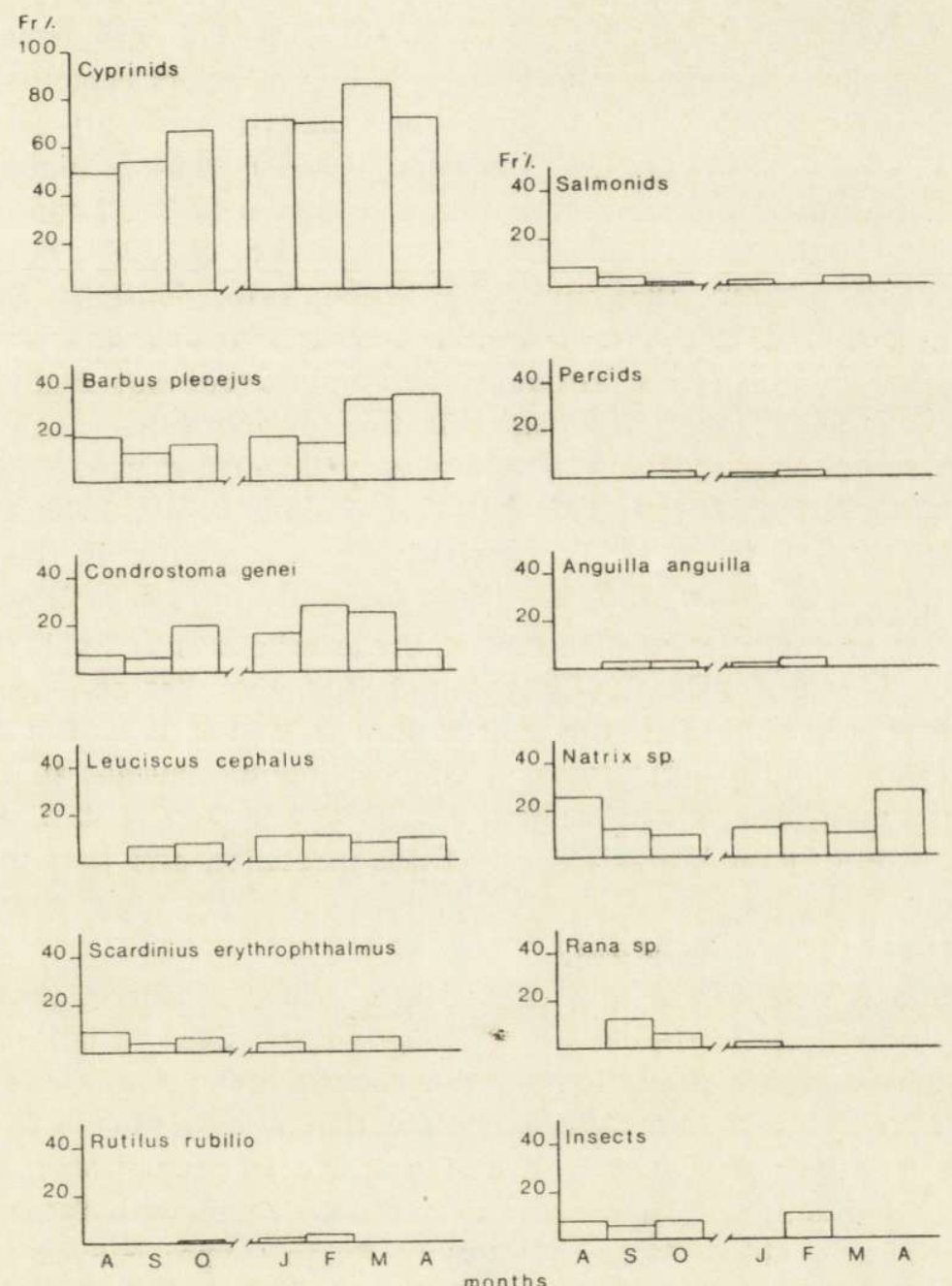

Fig. 2. The monthly distribution of the relative frequencies of the prey items eaten by the otter in Fiora River (no data were collected in November and' December 1982; FR $\%=$ relative frequency). 


\section{DISCUSSION}

Although the spraint sample examined is small, it seems to give a fairly complete picture of the otter's diet. From 148 spraints we we:e able to identify 17 prey categories. Similar results were obtained by Lopez-Nieves and Hernando Casal (1984), although they examined a sample of 2145 spraints gathered in Central Sierra Morena (Spain).

As to dietary variations of the otter on the Fiora River, partial information was obtained, since only a short period was considered. Nevertheless, some trends on the feeding habits of otters clearly appear. Cyprinids play a primary role in the otter's diet probably all year long, and occur with a mean relative frequency $(66.4 \%)$ that is higher than those found in other European countries (e.g. Spain: 55.7\%, Lopez-Nieves \& Hernando Casal, 1984; Albania: 37.9\%, Prigioni et al., 1986; Southwest England: $32.1 \%$, Chanin, 1981 and $8.3 \%$, Webb, 1975; Southern Sweden: $23.1 \%$, Erlinge, 1969). Moreover, several species of cyprinids are exploited. We identified eight species, although 41 spraints did not include any diagnostic elements for a fine classification of cyprinids. Instead we found that salmonids and eels, that are very important prey categories of food in Northwest Europe (Webb, 1975; Jenkins et al., 1979; Chanin, 1981; Gormally \& Fairley, 1982), were scarcely represented in the otter's diet, although restocking of these fishes generally occurs each year.

In a study on food habits of otters in different zones of Spain LopezNieves and Hernando Casal (1984) found that the diet in each zone included some characteristic species. In our case these prey items were Barbus plebejus and Condrostoma genei, fast moving species that occur preferentially on river stretches with a fairly rapid current. This suggests that otters forage prevalently in these stretches, and that the predation on the two species seems to be influenced by their abundance rather than by their vulnerability.

Besides fishes, we found that snakes are a food resource, that seem to occur in the otter's diet all year long with a fairly high relative frequency. The otter's predation on the snakes in winter seems to be favoured by a mild Mediterranean climate that allows snakes to maintain some activity. Snakes, as well as frogs, are frequent prey items of the otter in the south of its range and our data agree with those found. in Greece (Macdonald \& Mason, 1982b) in Spain (Lopez-Nieves \& Hernando Casal, 1984) and in Albania (Prigioni et al., 1986). But, unlike these authors, we found that snakes were more preyed on than frogs by otters.

The seasonal variation of flow in rivers is one of the principal factors that influences markedly the composition of the otter's diet (Lopez- 
Nievez \& Hernando Casal, 1984). The Fiora River shows a minimum flow in August, but it does not become dry and pools, where some categories of prey items, particularly fishes can be concentrated, do not occur. Therefore it is suggested that the otter's diet does not undergo any wide variations during the year, except the categories of food like snakes that in summer seem to be more abundant and easily caught in stretches of river with low water. In fact, in August we found that snakes occurred in the otter's diet with a high relative frequency $(25.0 \%)$. By contrast this does not happen for frogs.

The conservation of a good fish population is very important for the survival of the small population of otters on the Fiora River. For this purpose the cessation of gravel extraction, the establishment of a fishing reserve in places where otters are permanently present, and a control of angling are necessary.

Acknowledgements: We wish to thank Dr. S. M. Macdonald and Dr. C. F. Mason for critical reading of manuscript.

\section{REFERENCES}

Arcà G., 1986: La Lontra nel bacino del fiume Fiora. [In: Cassola F.(ed.) "La Lontra in Italia"]. W. W. F. Serie atti e Studi, 5: 81-87. - Calleyo A. \& Delibes H., (in press): Regime alimentaire de la Loutre Lutra lutra (L.) en Espagne. 3eme Colloque International sur la Loutre. Strasbourg, France. - Belfiore C., Bambacigno F., Lorenzi K. \& Minervini R. (in press): Qualità biologica dei fiumi Fiora e Albegna. CO.I.P.A., Roma. - Camby A., Le Gall O. \& Maizeret C., 1984: Atlas d'identification des restes alimentaires de la Loutre (premiers elements). Groupe Loutres, Bulletin de Liaison, n. 16. - Chanin P., 1981: The diet of the otter and its relations with the feral mink in two areas of Southwest England. Acta theriol., 26: 83-95. - Erlinge S., 1967: Food habits of the otter (Lutra lutra L.) in South Swedish habits. Viltrevy, 4: 371-438. - Erlinge S., 1969: Food habits of the otter (Lutra lutra L.) and the mink (M. vison) in Sweden.Oikos, 20: 1-7. - Fairley J. S., 1972: Food of otters (Lutra lutra), from Co. Galway, Ireland, and notes on other aspects of their biology. J. Zool. Lond., 166: 469-474. - Fairley J. S. \& Wilson S. C., 1972: Autumn food otters (Lutra lutra) on the Agivey River, County Landonderry, Northern Ireland. J. Zool. Lond., 166: 468-469. - Gormally M. J. \& Fairley J. S., 1982: Food of otters Lutra lutra in freshwater lough and an adjacent brackish lough in the west of Ireland. J. Zool. Lond., 197: 313-321. - Hewson R., 1973: Food and feeding habits of otters Lutra lutra at Loach Park, north-east Scotland. J. Zool. Lond., 170: 159-162. - Jenkins D. \& Harper R. J., 1980: Ecology of otters in Northern Scotland: II. Analysis of otter ( $L$. lutra) and mink (M. vison) faeces from Deeside, NE Scotland in 1977-78. J. anim. Ecol., 49: 737-754. Jenkins D., Walker J. G. K. \& McCowan D., 1979: Analyses of otter (Lutra lutra) faeces from Deeside, NE Scotland. J. Zool. Lond., 187: 235-244. - Lopez-Nieves P. \& Hernando Casal J. A., 1984: Food habits of the otter in the Central Sierra Morena (Cordoba, Spain). Acta theriol., 29: 383-401. - Macdonald S. M. \& Mason C. F., 1982a: The otter Lutra lutra in the Central Portugal. Biol. Conserv., 22: 207-215. - Macdonald S. M. \& Mason C. F., 1982b: Otters in Greece. Oryx, 
16: 240-244. - Mason C. F. \& Macdonald S. M., 1980: The winter diet of otter (Lutra lutra) on a Scottish sea loch. J. Zool. Lond., 192: 558-561. - Prigioni C., Bogliani G. \& Barbieri F., 1986: The otter Lutra lutra in Albania. Biol. Conserv. 36: 375-383. - Watson H., 1978: Coastal Otters in Shetland. Unpubl. Report to Vincent Wildlife Trust, London. - Webb J. B., 1975: Food of the otter (Lutra lutra) on the Somerset levels. J. Zool. Lond., 177: 486-491. - Webb J. B., 1976: Otter Spraint Analysis. An occasional Publication of the Mammal Society, London. - Wise M. H., Linn I. J. \& Kennedy S. M., 1981: A comparison of the feeding biology of mink, Mustela vison, and otter, Lutra lutra. J. Zool. Lond., 195: 181-213. Received, September 10, 1986. Accepted, November 20, 1986.

ACTA THERIOLOGICA

Vol. 32,10 : 140-144, 1987

\section{A Cost-Efficient Live Trap for Small Mammals}

TANIA ZYYWOZOWKA NA MAŁE SSAKI

Eric LE BOULENGE \& Paule Y. LE BOULENGE-NGUYEN

Le Boulengé E. \& Le Boulengé-Nguyen P. Y., 1987: A cost-efficient live trap for small mammals. Acta theriol., 32, 10: 140-144 [With 1 Fig.]

An efficient and easily home-made live trap for small mammals called the "WEB" trap, is described. It consists of a wooden box, with internal door and trigger mechanism made of galvanized iron plate. Our experience using the WEB trap intensively since ten years, totalling over 24,000 captures of small mammals, shows it to be a performant and inexpensive alternative to the commercial traps.

[Unité d'Ecologie et du Biogéographie, Université Catholique de Louvain, Place Croix du Sud, 5, B-1348 Louvain-la-Neuve, Belgium].

\section{INTRODUCTION}

Many devices have been developed to live-catch small mammals This mere civersity points to the fact that making a "good" live trap is not a simple matter (e.g. Bateman, 1971; Twigg, 1975; and DeBlase \& Martin, 1981). The ideal live trap should be attractive, sensitive, robust, reliable, escape-proof, inconspicuous, and easy to set, clean, carry and repair; it should offer the captured animal a good protection and, last but not least, be inexpensive (e.g. Rose, 1973). Probably no single live trap is optimal for all of the above criteria, and commercial traps especially 